Research Article

\title{
Bovine whey peptides transit the intestinal barrier to reduce oxidative stress in muscle cells
}

\author{
Alberto R. Corrochano ${ }^{\mathrm{a}, \mathrm{b}}$, Anita Ferraretto ${ }^{c}$, Elena Arranz ${ }^{\mathrm{a}}$, Milda Stuknytè ${ }^{\mathrm{d}}$, Michela Bottani ${ }^{\mathrm{c}}$, \\ Paula M. O'Connor ${ }^{\mathrm{a}}$, Phil M. Kelly ${ }^{\mathrm{a}}$, Ivano De Noni ${ }^{\mathrm{d}}$, Vitaly Buckin ${ }^{\mathrm{b}}$, Linda Giblin ${ }^{\mathrm{a}, *}$ \\ ${ }^{a}$ Teagasc Food Research Centre, Moorepark, Fermoy, Co Cork, Ireland \\ ${ }^{\mathrm{b}}$ School of Chemistry \& Chemical Biology, University College Dublin, Dublin 4, Ireland \\ ${ }^{\mathrm{c}}$ Dipartimento di Scienze Biomediche per la Salute, Università degli Studi di Milano, LITA, Segrate, Italy \\ ${ }^{\mathrm{d}}$ Dipartimento di Scienze per gli Alimenti, la Nutrizione e l'Ambiente, Università degli Studi di Milano, Milan, Italy
}

\section{A R T I C L E I N F O}

\section{Keywords:}

Whey peptides

Gastrointestinal digestion

Bioavailability

Antioxidant activity

Muscle cells

\begin{abstract}
A B S T R A C T
Health benefits are routinely attributed to whey proteins, their hydrolysates and peptides based on in vitro chemical and cellular assays. The objective of this study was to track the fate of whey proteins through the upper gastrointestinal tract, their uptake across the intestinal barrier and then assess the physiological impact to downstream target cells. Simulated gastrointestinal digestion (SGID) released a selection of whey peptides some of which were transported across a Caco-2/HT-29 intestinal barrier, inhibited free radical formation in muscle and liver cells. In addition, SGID of $\beta$-lactoglobulin resulted in the highest concentration of free amino acids $(176 \mathrm{nM})$ arriving on the basolateral side of the co-culture with notable levels of branched chain and sulphurcontaining amino acids. In vitro results indicate that consumption of whey proteins will deliver bioactive peptides to target cells.
\end{abstract}

\section{Introduction}

Bovine whey proteins are considered high quality proteins. They are a rich source of branched chain amino acids (BCAA), well balanced, have encrypted bioactive peptides and well documented health benefits to muscle, immune and redox systems (Patel, 2015). As such, the total whey world trade volume in 2015 was more than 1.7 million tonnes with the sports nutrition sector of particular importance (IDF, 2016). Bovine whey proteins are $\beta$-lactoglobulin ( $\beta$-LG, 50-60\%), $\alpha$-lactalbumin ( $\alpha$-LA, 15-25\%), bovine serum albumin (BSA, 6\%), lactoferrin (LF, $<3 \%$ ) and several immunoglobulins $(<10 \%)$.

BCAA make up $26 \%$ of the amino acid (AA) content of whey proteins and function to promote muscle protein synthesis via stimulation of the rapamycin (mTOR) pathway. In a recent study, 8 elderly men who consumed $1.9 \mathrm{~g}$ native whey protein $/ \mathrm{kg}$ lean body weight for 10 days, had significantly higher levels of myosin and mitochondrial muscle protein synthesis than baseline, whereas consumption of casein had no effect. This benefit of whey was attributed to the high content of BCAA $(1159 \mu \mathrm{M})$ in their plasma (Walrand et al., 2016). Essential amino acids (EAA) function to reduce muscle inflammation after strenuous exercise. Purpura et al. (2014) observed that consumption of $48 \mathrm{~g}$ of commercial whey protein isolate (WPI) resulted in $229.5 \mathrm{nmol}$
$\mathrm{EAA} / \mathrm{mL}$ plasma in 10 resistance-trained men 67 min later. Bioactive peptides derived from whey proteins, if bioavailable, may also play a role in muscle health as suggested by in vitro data using whey hydrolysates directly on the $\mathrm{C} 2 \mathrm{C} 12$ muscle cell line, for instance, activating the mTOR complex I (Roeseler et al., 2017). However, the effect of whey on muscle is not without controversy with some studies showing limited or no effects on muscle after whey consumption or compared with casein supplementation (Agin et al., 2001; Tipton et al., 2004).

Whey proteins are rich in antioxidant AA including the glutathione precursor Cys (Fox, Uniacke-Lowe, McSweeney, \& O'Mahony, 2015). The once-off consumption of $3 \mathrm{~g}$ dairy product $(2.25 \mathrm{~g}$ milk protein concentrate plus $0.75 \mathrm{~g}$ whey hydrolysates) per $\mathrm{kg}$ body weight significantly increased the antioxidant capacity of plasma in 8 healthy women compared to baseline, albeit no control diet was included (Power-Grant et al., 2016). However, consumption of whey had no effect on antioxidant biomarkers in plasma in other studies (Kim, Paik, Yoon, \& Park, 2013; Middleton, Jelen, \& Bell, 2004). Several individual whey peptides such as $\beta$-LG $\mathrm{f}(19-29)$ WYSLAMAASDI, $\beta$-LG $\mathrm{f}(42-46)$ YVEEL, $\beta$-LG f(145-149) MHIRL, $\alpha$-LA f(101-104) INYW and $\alpha$-LA $f$ (115-118) LDQW have demonstrated antioxidant activity using in vitro chemical assays (Hernández-Ledesma, Dávalos, Bartolomé, \& Amigo, 2005; Sadat et al., 2011).

\footnotetext{
* Corresponding author.

E-mail address: linda.giblin@teagasc.ie (L. Giblin).
} 
The ability of whey proteins to reduce the pro-inflammatory cytokines, IL-1 $\beta$ and IL-6, was proposed as the mechanism by which a 16 day diet containing $20 \%$ whey protein protected D-galactosaminetreated rats against hepatotoxicity (Kume, Okazaki, \& Sasaki, 2006). A 28 day diet containing $10 \%$ WPI also protected stressed rats against liver damage by decreasing lipid peroxidation and increasing plasma levels of the antioxidant tripeptide glutathione (Ashoush, El-Batawy, \& El-Shourbagy, 2013).

However, little is known about which whey peptides survive the harsh conditions of the gastrointestinal tract and are absorbed, via passive or active transport, across the intestinal barrier to reach target organs. Recently, whey protein degradation during upper gut transit was tracked in human jejunal effluents and using in vitro simulated gastrointestinal digestion (SGID) protocols (Sanchón et al., 2018). SGID is a suitable model to predict whey protein digestion as demonstrated by a correlation coefficient of 0.74 for $\beta$-LG and $\alpha$-LA (Sanchón et al., 2018).

Several studies have employed differentiated Caco-2 monolayers to assess the intestinal absorption of individual milk-derived peptides and AA (Goulart et al., 2014; Picariello et al., 2013). For example, Vermeirssen et al. (2002) demonstrated the transport of anti-hypertensive peptide from $\beta$-LG, lactokinin $\mathrm{f}(142-148)$ ALMPHIR, across Caco-2 clone Bbe monolayers cultured in Ussing chambers.

The objective of this study was to investigate the bioavailability of SGID commercial whey products and individual whey proteins across Caco-2/HT-29 co-culture to mimic upper gut transit of whey and transport across the intestinal barrier. By secreting mucus, the adenocarcinoma HT-29 improves the Caco-2 model. Using Peptide Ranker score, known bioavailability, presence of known antioxidant AA or presence of BCAA, 6 bioavailable peptides were selected and assayed for their ability to promote antioxidant status in muscle and liver cells and modulate cytokine markers in immune cells.

\section{Materials and methods}

\subsection{Materials}

Commercial bovine WPI (Isolac, 91.4\% protein content) was purchased from Carbery Food Ingredients (Ireland). $\beta$-LG (92.1\% $\beta$-LG content) and $\alpha$-LA (93\% $\alpha$-LA content) were obtained from Davisco Foods International (USA). LF (Bioferrin 2000, 95\% of LF and $0.02 \%$ of iron) was gifted by Glanbia Nutritionals (USA). BSA ( $98 \%$ protein content) was purchased from Sigma-Aldrich (Ireland). Milk-proteinbased sport product (MPSPO, 47\% protein content: WPI, whey protein concentrate, calcium caseinate, milk protein concentrate) was purchased from a local retailer. Human TNF- $\alpha$ and IL-1 $\beta / \mathrm{IL}-1 \mathrm{~F} 2$ DuoSet ELISA kits and DuoSet Ancillary Reagent Kit 2 were from R\&D Systems (UK). All other reagents were purchased from Sigma-Aldrich.

\section{2. $S G I D$}

SGID was performed as described by Minekus et al. (2014). Whey protein samples (WPI, $\beta$-LG, $\alpha$-LA, BSA and LF) ( $1 \mathrm{~g}$ powder, which contained approximately $0.94 \mathrm{~g}$ protein) were reconstituted in $5 \mathrm{~mL}$ of Milli-Q $\mathrm{H}_{2} \mathrm{O}$. MPSPO was reconstituted at $1.5 \mathrm{~g}$ powder $/ 5 \mathrm{~mL} \mathrm{H}_{2} \mathrm{O}$ ( $0.71 \mathrm{~g}$ protein) following manufacturer's recommendations. As they were liquid formulations, no oral phase was performed. Gastric phase was performed for $2 \mathrm{~h}$ using porcine pepsin $(2000 \mathrm{U} / \mathrm{mL})$. Intestinal phase was performed for $2 \mathrm{~h}$ using pancreatin $(100 \mathrm{U} / \mathrm{mL})$ and bile extract $(10 \mathrm{mM})$. To stop the intestinal phase, protease inhibitor 4-(2aminoethyl) benzenesulfonyl fluoride hydrochloride $(1 \mathrm{mM})$ was added. Samples were snap frozen in liquid nitrogen and stored at $-80^{\circ} \mathrm{C}$. Prior to cell exposures, the osmolarity of SGID proteins was measured by Osmometer Basic (Löser Messtechnik, Germany) and corrected to $300 \mathrm{mOsm} / \mathrm{kg} \mathrm{H} \mathrm{H}_{2} \mathrm{O}$ (physiological) using distilled $\mathrm{H}_{2} \mathrm{O}$.

\subsection{Cell lines}

Cells were grown in $75 \mathrm{~cm}^{2}$ tissue culture flasks with the correspondent culture medium and kept in a humidified incubator with a $5 \%$ $\mathrm{CO}_{2}$ air atmosphere at $37^{\circ} \mathrm{C}$. The intestinal cell lines, Caco-2 (BSTCL87) and HT-29 (BSTCL132), were purchased from Istituto Zooprofilattico Sperimentale di Brescia (Italy). Routinely, Caco-2 and HT-29 cells were cultured separately in Minimum Essential Medium Eagle (MEM) and Roswell Park Memorial Institute-1640 (RPMI-1640) medium respectively, supplemented with $10 \%$ foetal bovine serum (FBS), $2 \mathrm{mM} \mathrm{L-}$ glutamine, antibiotics $(100 \mathrm{U} / \mathrm{mL}$ penicillin and $100 \mu \mathrm{g} / \mathrm{mL}$ streptomycin) and $1 \mathrm{mM}$ sodium pyruvate (only for MEM). Murine myoblasts C2C12 (ATCCCRL-1772), human hepatocyctes HepG2 (ATCCHB-8065) and human monocytes THP-1 (ATCCTIB-202) were purchased from American Type Culture Collection (USA). C2C12 cells were maintained in DMEM supplemented with $10 \%$ FBS, $100 \mathrm{U} / \mathrm{mL}$ penicillin and $100 \mu \mathrm{g} / \mathrm{mL}$ streptomycin. Hepatocytes were cultured in MEM supplemented with $10 \%$ FBS, $2 \mathrm{mM}$ L-glutamine, $1 \%$ non-EAA, $100 \mathrm{U} / \mathrm{mL}$ penicillin and $100 \mu \mathrm{g} / \mathrm{mL}$ streptomycin. Monocytes were cultured in RPMI-1640 medium supplemented with 10\% FBS and antibiotics (100 U/mL penicillin and $100 \mu \mathrm{g} / \mathrm{mL}$ streptomycin). Passage numbers were between 25 and 40 (Caco-2), 10-25 (HT-29), 6-9 (C2C12), 20-25 (HepG2) and 15-20 (THP-1).

\subsection{Co-cultures}

$70 \%$ of Caco-2 and $30 \%$ of HT-29 cells were seeded together in RPMI-1640 at a density of $4 \times 10^{4}$ cells/cm, as previously described by Ferraretto et al. (2018). Cell confluence was achieved 4 days after seeding. After 6 days post confluence, transport studies were performed. After 6 days post confluence, co-culture cells showed the presence of (1) microvilli with active enzymes, (2) mucus and (3) barrier properties characterized by a permeability value similar to the human small intestine in vivo (Ferraretto et al., 2018).

\subsection{Cytotoxicity}

Co-cultures growing in 24 well plates were incubated for $2 \mathrm{~h}$ with SGID proteins prepared in complete RPMI-1640. Cells were washed with PBS and MTT assays performed using $510 \mu \mathrm{L}$ thiazolyl blue tetrazolium bromide solution $(98 \mu \mathrm{g} / \mathrm{mL}$ ) in RPMI- 1640 for $4 \mathrm{~h}$, followed by $400 \mu \mathrm{L}$ DMSO. Absorbance was expressed as relative $\%$ of untreated co-culture.

\subsection{Co-culture transport studies}

Co-cultures were grown in Transwell $^{\circledR}$ Millicell $^{\circledR} 24$ insert plates $(1.0 \mu \mathrm{m})$ assembled to a Millicell ${ }^{\circledR} 24$ well receiver tray (EMD Millipore, USA) and maintained in complete RPMI-1460 medium. Transepithelial electrical resistance (TEER) was measured at $37^{\circ} \mathrm{C}$ on 0,3 and 6 days post-confluence using a Millicell ${ }^{\oplus}$-ERS voltohmmeter (EMD Millipore, USA).

On treatment days, TEER values were recorded, and then co-cultures were gently washed 3 times with Hank's Balanced Salt Solution (HBSS) and incubated for $30 \mathrm{~min}$ in $\mathrm{HBSS}$ at $37^{\circ} \mathrm{C}$. After the acclimatisation period, $175 \mu \mathrm{g}$ SGID proteins in $400 \mu \mathrm{L}$ HBSS were added to the apical side of the inserts $\left(0.7 \mathrm{~cm}^{2}\right.$ surface area, equates to $\left.250 \mu \mathrm{g} / \mathrm{cm}^{2}\right)$ and $800 \mu \mathrm{L}$ HBSS were added to the basolateral compartments. TEER values were monitored immediately and then again, at $1 \mathrm{~h}$ and $2 \mathrm{~h}$. After the $2 \mathrm{~h}$ treatment, apical and basolateral solutions were collected and stored at $-40{ }^{\circ} \mathrm{C}$ prior to analysis.

The paracellular permeability was determined using the fluorescent probe lucifer yellow as previously described by Ferraretto et al. (2018). Co-cultures were treated at 6 days post confluence with $175 \mu$ g SGID proteins together with $100 \mu \mathrm{M}$ lucifer yellow in HBSS. After $2 \mathrm{~h}$, apical and basolateral solutions were collected and the fluorescence was 
measured at excitation of $398 \mathrm{~nm}$ and emission of $518 \mathrm{~nm}$ using a fluorescence spectrometer (Perkin Elmer, UK). The apparent permeability coefficient $\left(\mathrm{P}_{\text {app }}\right.$ ) was calculated following the equation:

$\mathrm{P}_{\mathrm{app}}(\mathrm{cm} / \mathrm{s})=\left[1 /\left(\mathrm{S} * \mathrm{C}_{0}\right)\right] * \mathrm{dQ} / \mathrm{dt}$

where $S$ is the surface area of the insert $\left(0.7 \mathrm{~cm}^{2}\right), \mathrm{C}_{0}$ is initial concentration of lucifer yellow added in the apical side and dQ/dt is the amount of lucifer yellow detected in the basolateral compartment as a function of time ( $\mu \mathrm{mol} / \mathrm{s})$ (Ferraretto et al., 2018).

Co-cultures incubated only with lucifer yellow were included as controls. The transport of lucifer yellow through inserts without coculture was determined at $4.3 \times 10^{-6} \mathrm{~cm} / \mathrm{s}$.

\subsection{Amino acid determination}

The protocol described by McDermott et al. (2016) was followed to determine the free AA in apical and basolateral compartments using Jeol JLC-500/V AA analyzer (Jeol, Welwyn Garden City, UK) fitted with a Jeol $\mathrm{Na}+$ high performance cation exchange column.

\subsection{Peptide identification}

Peptides in the apical and basolateral solutions were identified by UPLC-HR-MS using an Acquity UPLC module (Waters, USA) fitted to a Q Exactive hybrid quadrupole-Orbitrap mass spectrometer (Thermo Scientific, USA). The samples were eluted on an Aeris PEPTIDE XB-C18 column $(150 \times 2.1 \mathrm{~mm}, 1.7 \mu \mathrm{m}, 100 \AA)$ with a SecurityGuard ULTRA cartridge (Phenomenex, USA) following the analytical conditions previously described (Corrochano et al., 2018). Peptide sequences were identified with the Proteome Discoverer 1.4 software (Thermo Scientific, USA) using the Bos taurus database (UniProt taxon ID 9913) as reported in Corrochano et al. (2018). Briefly, settings were as follows: mass accuracy window for precursor ions, $5 \mathrm{ppm}$; mass accuracy window for fragment ions, $0.02 \mathrm{Da}$; no fixed modifications; variable modifications: phosphorylation of Ser and Thr, deamidation of Asn, Gln and Arg, oxidation of Met and cyclisation of an $N$-terminal Gln to pyroglutamic acid. Peptides were searched using the Sequest engine (Eng, McCormack, \& Yates, 1994), which is included into the PD 1.4 software and allows the identification of peptides as short as two amino acids (M. Scigelova, personal communication). A strict false discovery rate of peptide identification was set $(\mathrm{FDR}=0.01)$.

The peptides ALPM, GDLE, TKIPA, VEELKPT from $\beta$-LG, VGIN from $\alpha$-LA and AVEGPK from BSA were synthesised and purified following the method previously described by Lafarga, Aluko, Rai, O'Connor, and Hayes (2016) and using the resins: H-Met-HMPB-ChemMatrix, H-AlaHMPB-ChemMatrix, H-Asn-HMPB-ChemMatrix, H-Glu-HMPB-ChemMatrix, H-Thr-HMPB-ChemMatrix and H-Lys-HMPB-ChemMatrix (PCAS Biomatrix Inc., Canada). Each peptide eluted in a single peak.

\subsection{Cellular antioxidant activity}

Synthetic peptides were tested for cellular antioxidant activity using C2C12 and HepG2 cells. C2C12 or HepG2 were seeded at $8 \times 10^{4}$ cells/ well in 96 well plates, in their culture medium, for 24 or $48 \mathrm{~h}$, respectively. Before treatment, cells were washed twice with PBS and treated with $50 \mu \mathrm{L}$ of each peptide (final concentrations: 2.5 or $5 \mathrm{mM}$ were selected based on previous in vitro studies by others (Komatsu et al., 2019; Lacroix, Chen, Kitts, \& Li-Chan, 2017; Le Nevé \& Daniel, 2011)), reconstituted in HBSS. 2',7'-dichlorofluorescin di-acetate (DCFH-DA, $50 \mu \mathrm{L}(25 \mu \mathrm{M}$ final)) was added for $1 \mathrm{~h}$. Cells were washed

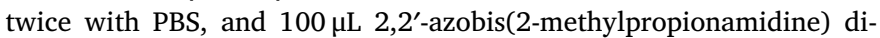
hydrochloride (ABAP, $600 \mu \mathrm{M}$ in HBSS) was added. The plate was immediately placed in a Synergy HT BioTek micro plate reader (USA) at $37^{\circ} \mathrm{C}$. Fluorescence was registered every minute for $1 \mathrm{~h}$ with excitation at $485 \mathrm{~nm}$ and emission at $535 \mathrm{~nm}$. Negative control (cells treated only with HBSS and DCFH-DA) and positive control for cellular oxidation

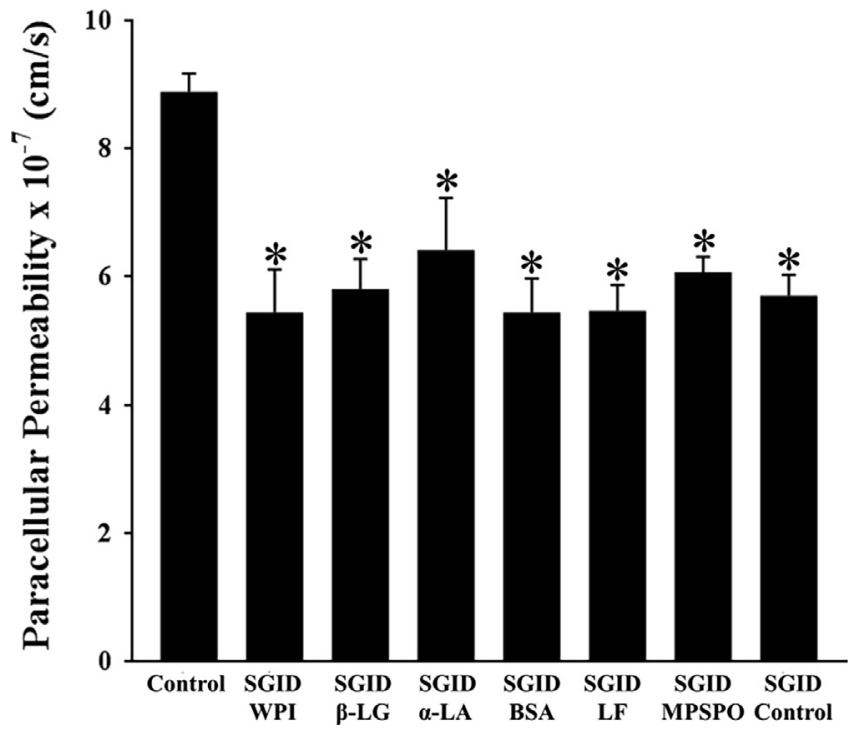

Fig. 1. Caco-2/HT-29 (70:30) paracellular permeability after $2 \mathrm{~h}$ treatment with $175 \mu$ g simulated gastrointestinal digested (SGID) whey samples: WPI, $\beta$ LG, $\alpha$-LA, BSA, LF, MPSPO, SGID control (gastrointestinal fluids with gut enzymes, bile salts and electrolytes). Caco-2/HT-29 were seeded together at a density of $4 \times 10^{4}$ cells $/ \mathrm{cm}^{2}$. Paracellular permeability was measured by lucifer yellow quantification in the basolateral compartment as a \% of initial apical concentration $(100 \mu \mathrm{M})$ in the presence of SGID samples. ${ }^{*} \mathrm{p}<0.05$ indicates significant difference to untreated cells (Control).

(cells incubated only with ABAP) were included. $N$-acetylcysteine (NAC) was used at 2.5 or $5 \mathrm{mM}$ (final concentrations) as the positive control for antioxidant protection. The assay was performed in triplicate on two different days.

\subsection{Immunomodulatory activity}

THP-1 cells were seeded at $5 \times 10^{5}$ cells/well in 24 well plates. Cells were maintained for $48 \mathrm{~h}$ in complete culture medium supplemented with $100 \mathrm{ng} / \mathrm{mL}$ of phorbol 12-myristate 13-acetate (PMA) to induce macrophage differentiation. Fresh medium without PMA was added, and cells were grown for $24 \mathrm{~h}$. Macrophages were then washed with PBS and stimulated with $0.05 \mu \mathrm{g} / \mathrm{mL}$ lipopolysaccharide (LPS) in the presence of peptides $(1 \mu \mathrm{M}-5 \mathrm{mM})$ for $24 \mathrm{~h}$ in medium without FBS. After treatment, supernatants were collected and frozen at $-80^{\circ} \mathrm{C}$. Cytokines TNF- $\alpha$ and IL-1 $\beta$ were quantified in supernatants by ELISA.

\subsection{Peptide cytotoxicity}

C2C12 or HepG2 cells were seeded at $8 \times 10^{4}$ cells/well in 96 well plates and allowed to reach confluence for 24 or $48 \mathrm{~h}$, respectively. Cells were washed twice with PBS and treated with peptides (2.5 or $5.0 \mathrm{mM}$ ) reconstituted in HBSS for $1 \mathrm{~h}$. Control cells were incubated only with HBSS. After treatment, cells were washed once with PBS and incubated with $50 \mu \mathrm{L}$ MTT $(0.5 \mathrm{mg} / \mathrm{mL})$ in complete medium. For THP1 , cells were differentiated in 24 well plates and then exposed to peptides $(1 \mu \mathrm{M}-5 \mathrm{mM})$ for $24 \mathrm{~h}$. Supernatants were removed and $500 \mu \mathrm{L}$ MTT solution $(0.5 \mathrm{mg} / \mathrm{mL})$ were added. After $3 \mathrm{~h}$, MTT solution was removed, $50 \mu \mathrm{L}$ (or $500 \mu \mathrm{L}$ for THP-1 cells) of 1:1 DMSO:ethanol were added and absorbance read at $570 \mathrm{~nm}$ in a Synergy HT microplate reader. Cell viability was calculated as a percentage of control.

\subsection{Statistical analysis}

Co-culture experiments were performed in duplicate on 3 different days. Cellular antioxidant assays were performed in triplicate on 2 different days. Cellular exposures to determine pro-inflammatory 
Table 1

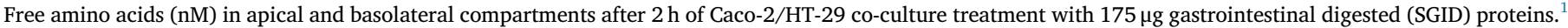

\begin{tabular}{|c|c|c|c|c|c|c|c|}
\hline Amino acid (nM) & & SGID WPI & SGID $\beta$-LG & SGID $\alpha$-LA & SGID BSA & SGID LF & SGID MPSPO \\
\hline \multirow[t]{2}{*}{ Ala } & Apical & 46.4 & 46.9 & 29.6 & 40.6 & 47.9 & 34.8 \\
\hline & Basolateral & 21.6 & 23.8 & 18.4 & 21.1 & 18.9 & 16.1 \\
\hline \multirow[t]{2}{*}{ Arg } & Apical & 27.8 & 28.5 & 18.8 & 46.8 & 60.0 & 34.8 \\
\hline & Basolateral & 23.6 & 22.5 & 21.6 & 23.7 & 20.9 & 20.1 \\
\hline \multirow[t]{2}{*}{ Asp } & Apical & 6.8 & 6.5 & 8.4 & 3.9 & 6.7 & 5.9 \\
\hline & Basolateral & 0.8 & 1.9 & 1.3 & 1.3 & 1.2 & 1.3 \\
\hline \multirow[t]{2}{*}{ Cysteic acid } & Apical & 9.2 & 3.3 & 3.6 & 3.2 & 6.1 & 12.9 \\
\hline & Basolateral & 2.6 & 2.7 & 2.7 & 2.8 & 2.9 & 1.6 \\
\hline \multirow[t]{2}{*}{ Cys } & Apical & 19.1 & 14.8 & 18.2 & 14.8 & 16.8 & 14.0 \\
\hline & Basolateral & 10.3 & 10.2 & 6.9 & 9.4 & 9.2 & 9.9 \\
\hline \multirow[t]{2}{*}{ Glu } & Apical & 29.3 & 22.1 & 37.9 & 24.0 & 19.6 & 25.4 \\
\hline & Basolateral & 4.2 & 5.2 & 5.0 & 4.8 & 4.2 & 4.0 \\
\hline \multirow[t]{2}{*}{ Gly } & Apical & 11.5 & 9.4 & 18.7 & 9.8 & 18.9 & 13.3 \\
\hline & Basolateral & 4.5 & 4.2 & 4.9 & 4.6 & 5.2 & 4.3 \\
\hline \multirow[t]{2}{*}{ His } & Apical & 24.0 & 23.9 & 21.7 & 30.0 & 28.7 & 25.8 \\
\hline & Basolateral & 8.2 & 9.1 & 7.7 & 8.2 & 7.6 & 7.3 \\
\hline \multirow[t]{2}{*}{ Ile } & Apical & 36.3 & 31.4 & 35.7 & 14.9 & 20.7 & 24.8 \\
\hline & Basolateral & 8.9 & 9.7 & 9.6 & 8.0 & 7.3 & 7.8 \\
\hline \multirow[t]{2}{*}{ Leu } & Apical & 92.6 & 100.0 & 72.9 & 82.9 & 79.1 & 78.8 \\
\hline & Basolateral & 11.7 & 17.9 & 12.3 & 13.7 & 11.5 & 11.1 \\
\hline \multirow[t]{2}{*}{ Lys } & Apical & 83.3 & 79.4 & 88.5 & 69.8 & 70.5 & 73.4 \\
\hline & Basolateral & 7.8 & 11.5 & 8.9 & 9.1 & 7.5 & 7.4 \\
\hline \multirow[t]{2}{*}{ Met } & Apical & 16.0 & 15.1 & 10.6 & 5.1 & 8.4 & 13.0 \\
\hline & Basolateral & 2.1 & 2.9 & 1.9 & 1.6 & 1.5 & 1.7 \\
\hline \multirow[t]{2}{*}{ Phe } & Apical & 30.2 & 26.7 & 36.7 & 56.9 & 47.2 & 36.5 \\
\hline & Basolateral & 3.8 & 5.1 & 5.0 & 5.7 & 4.7 & 4.4 \\
\hline \multirow[t]{2}{*}{ Ser } & Apical & 18.5 & 17.8 & 13.1 & 19.5 & 22.3 & 18.9 \\
\hline & Basolateral & 6.0 & 6.4 & 6.5 & 6.7 & 6.0 & 5.2 \\
\hline \multirow[t]{2}{*}{ Tau } & Apical & 8.5 & 7.5 & 8.9 & 7.2 & 8.0 & 8.2 \\
\hline & Basolateral & 10.8 & 9.2 & 8.9 & 9.4 & 9.0 & 5.0 \\
\hline \multirow[t]{2}{*}{ Thr } & Apical & 39.8 & 26.1 & 40.2 & 31.3 & 36.8 & 30.0 \\
\hline & Basolateral & 11.4 & 10.6 & 11.1 & 11.8 & 9.2 & 9.2 \\
\hline \multirow[t]{2}{*}{ Trp } & Apical & 45.5 & 35.6 & 79.0 & 23.2 & 53.6 & 34.8 \\
\hline & Basolateral & 6.0 & 5.7 & 6.5 & 4.5 & 4.6 & 5.5 \\
\hline \multirow[t]{2}{*}{ Tyr } & Apical & 27.5 & 29.5 & 31.6 & 41.5 & 33.0 & 32.6 \\
\hline & Basolateral & 4.9 & 5.7 & 5.4 & 5.6 & 5.1 & 5.6 \\
\hline \multirow[t]{2}{*}{ Val } & Apical & 48.7 & 37.1 & 40.3 & 41.5 & 45.8 & 38.1 \\
\hline & Basolateral & 9.8 & 12.2 & 6.6 & 9.8 & 9.3 & 9.5 \\
\hline \multirow[t]{2}{*}{ Total } & Apical & 621.1 & 561.7 & 614.4 & 566.9 & 630.0 & 556.0 \\
\hline & Basolateral & 159.1 & 176.5 & 151.2 & 161.9 & 145.8 & 137.1 \\
\hline
\end{tabular}

\footnotetext{
1 WPI = Whey protein isolate.

$\beta$-LG $=\beta$-Lactoglobulin.

$\alpha$-LA $=\alpha$-Lactalbumin.

BSA $=$ Bovine serum albumin

$\mathrm{LF}=$ Lactoferrin.
}

MPSPO = Milk protein sport product.

biomarkers were performed in duplicate on 2 different days. One-way ANOVA followed by Bonferroni's Multiple Comparison post-hoc test was employed to compare results using the PASW Statistics 18 software. P-value $<0.05$ indicated statistical significance. Results were expressed as means \pm standard deviations.

\section{Results}

\subsection{Co-culture integrity and cytotoxicity of SGID proteins}

Whey products (WPI, MPSPO) and individual whey proteins ( $\beta$-LG, $\alpha$-LA, BSA, LF) were subjected to static upper SGID in duplicate. As SGID samples can be cytotoxic to cells, 3 concentrations were initially tested $\left(10.5,50.0,250.0 \mu \mathrm{g}\right.$ protein $\left./ \mathrm{cm}^{2}\right)$ by MTT assay. These initial concentrations were selected based on the total surface area of the small intestine $\left(200 \mathrm{~m}^{2}\right)$ together with (a) the recommended intake of MSPSO ( $21 \mathrm{~g}$ protein/day) which equates to $10 \mu \mathrm{g}$ protein $/ \mathrm{cm}^{2}$, (b) daily high protein intake in a western diet $(100 \mathrm{~g} /$ day $)\left(50 \mu \mathrm{g}\right.$ protein $\left./ \mathrm{cm}^{2}\right)$ or $(\mathrm{c})$ a 5 fold increase to compensate for in vitro lack of microclimate $\left(250.0 \mu \mathrm{g}\right.$ protein $\left./ \mathrm{cm}^{2}\right)$. None of the tested SGID sample concentrations $\left(10.5,50.0,250.0 \mu \mathrm{g}\right.$ protein $\left./ \mathrm{cm}^{2}\right)$ were cytotoxic to Caco-2/HT-29co- culture (Fig. S1A) so the highest concentration was selected $(250.0 \mu \mathrm{g}$ protein $/ \mathrm{cm}^{2}$ ) to proceed to transport studies.

After 6 days post confluence, co-cultures showed absorptive and secretive enteric phenotypes (Ferraretto et al., 2018) allowing commencement of transport studies with SGID samples. Co-culture integrity was monitored during transport studies at 0,1 and $2 \mathrm{~h}$. TEER values were not altered due to sample exposure $\left(190-250 \Omega / \mathrm{cm}^{2}\right)$ and did not significantly change over time (Fig. S1B).

To evaluate if SGID proteins $\left(250 \mu \mathrm{g}\right.$ protein $\left./ \mathrm{cm}^{2}\right)$ interfered with intestinal epithelium permeability, the transport of the fluorescent probe lucifer yellow was assessed (Fig. 1). The permeability of the lucifer yellow through the untreated co-culture was $8.9 \times 10^{-7} \mathrm{~cm} / \mathrm{s}$. All SGID protein samples, including SGID control (gastrointestinal fluids with gut enzymes and bile extract), reduced intestinal permeability from $5.1 \times 10^{-7}$ to $6.1 \times 10^{-7} \mathrm{~cm} / \mathrm{s}$.

\subsection{Free amino acids transport}

Free AA were quantified in the apical and basolateral compartments after incubating Caco-2/HT-29 co-cultures with SGID proteins for $2 \mathrm{~h}$ (Table 1). The apical sample from LF treated co-cultures had the highest 


\section{SGID Whey Protein Isolate}

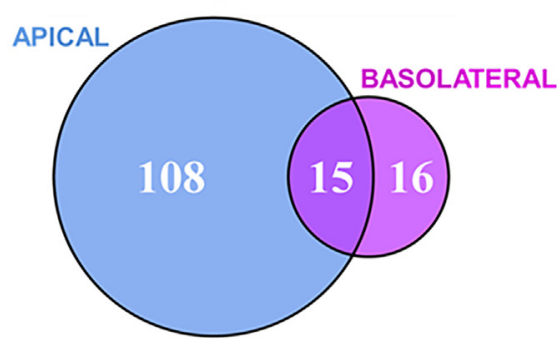

SGID Bovine Serum Albumin

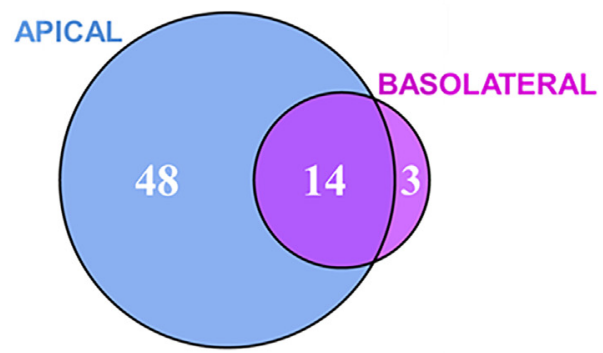

SGID $\alpha$-Lactalbumin

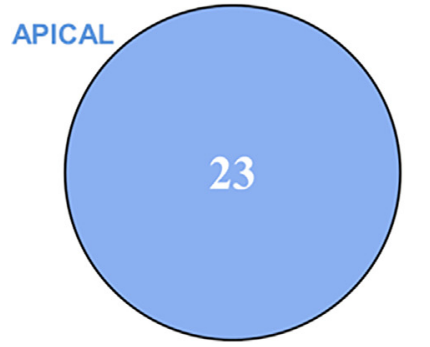

SGID $\beta$-Lactoglobulin

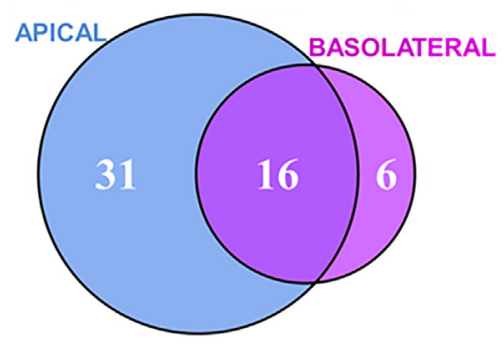

SGID Milk Protein Sport Product

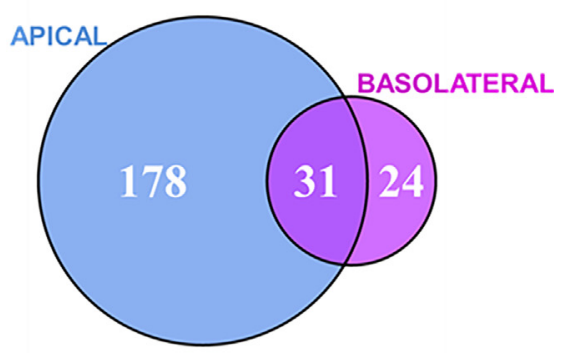

SGID Lactoferrin

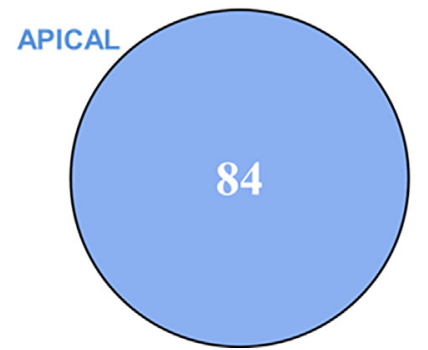

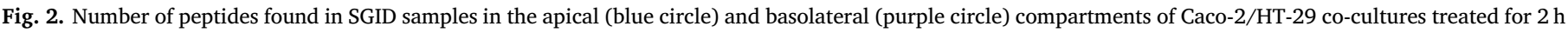

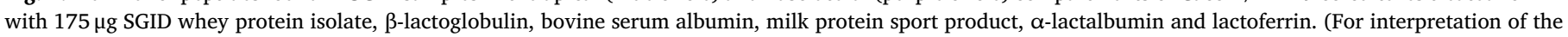
references to colour in this figure legend, the reader is referred to the web version of this article.)

concentration of free AA ( $630 \mathrm{nM})$, followed by the apical samples from WPI $(621.1 \mathrm{nM})$ and $\alpha$-LA $(614.4 \mathrm{nM})$. Leu $(72.9-100 \mathrm{nM})$ and Lys $(69.8-88.5 \mathrm{nM})$ were the most abundant AA in the apical compartments. Analysis of the basolateral compartments revealed that the amount of free AA was highest for $\beta$-LG $(176.5 \mathrm{nM})$, BSA $(161.9 \mathrm{nM})$ and WPI (159.1 nM) treated co-cultures. Most abundant AA in the basolateral solutions of co-cultures treated with whey proteins were Arg (20.1-23.7 nM), Ala (16.1-23.8 nM) and Leu (11.1-18.0 nM). Co-cultures treated with $\beta$-LG had the highest concentration of EAA (84.7 $\mathrm{nM})$, BCAA $(39.9 \mathrm{nM})$ and sulphur-containing AA $(15.9 \mathrm{nM})$ in the basolateral solution (Table 1). The antioxidant AA, Trp, was the most abundant in the basolateral sample collected from co-cultures treated with $\alpha$-LA $(6.5 \mathrm{nM})$.

\subsection{Peptide transport}

Peptide sequences identified by UPLC-HR-MS in the apical and basolateral samples from co-cultures treated with SGID whey samples are listed in Tables S1-S6.

The apical solution of WPI-treated co-cultures contained 123 peptides of which 15 were also detected in the basolateral solution with a further 16 unique to basolateral (Fig. 2). The apical solution of $\beta$-LG showed 47 peptides with 16 common to basolateral and 6 peptides exclusive to the basolateral compartment. The apical solution of BSAtreated cells yielded 62 peptides of which 14 were common to basolateral and a further 3 unique to the basolateral solution. The MPSPO showed 209 peptides, including casein peptides, in the apical solution with 31 common to basolateral and 24 additional peptides in the basolateral compartment. Whereas 23 and 84 peptides were identified in the apical side of $\alpha$-LA- and LF-treated co-cultures respectively, no peptides were identified in the corresponding basolateral solutions at the $250 \mu \mathrm{g}$ protein $/ \mathrm{cm}^{2}$ concentration tested.

From the peptides identified in basolateral solutions, 6 peptides were synthetized for bioactivity testing based on (a) a high Peptide Ranker score (ALPM (derived from $\beta-L G$ ) $=0.82$, Table S1), (b) known bioavailability (GDLE ( $\beta$-LG) and VEELKPT ( $\beta$-LG)), (c) presence of known antioxidant AA (ALPM, AVEGPK (BSA), GDLE and TKIPA ( $\beta-L G)$ or (d) presence of BCAA (VEELKPT, VGIN ( $\alpha$-LA)).

\subsection{Cellular antioxidant protection of milk peptides}

The antioxidant benefit to muscle cells of the synthesised peptides were investigated by measuring the peptide ability to inhibit intracellular peroxyl radical formation in a mouse muscle cell line C2C12 (Fig. 3A). Results were expressed as \% of cells treated only with the radical producer ABAP, considered as $100 \%$ cellular oxidative stress. Peptide VEELKPT at both concentrations tested $(2.5,5 \mathrm{mM})$ significantly reduced C2C12 viability (72.4\% and 93.8\%, respectively) and was therefore omitted. Peptides ALPM, GDLE, VGIN and AVEGPK $(5 \mathrm{mM})$ reduced cellular oxidation in ABAP-treated muscle cells, $34.4 \%-53 \%$, compared to the free radical control and similar to the effect obtained with the antioxidant molecule NAC (31.8\%). For HepG2 

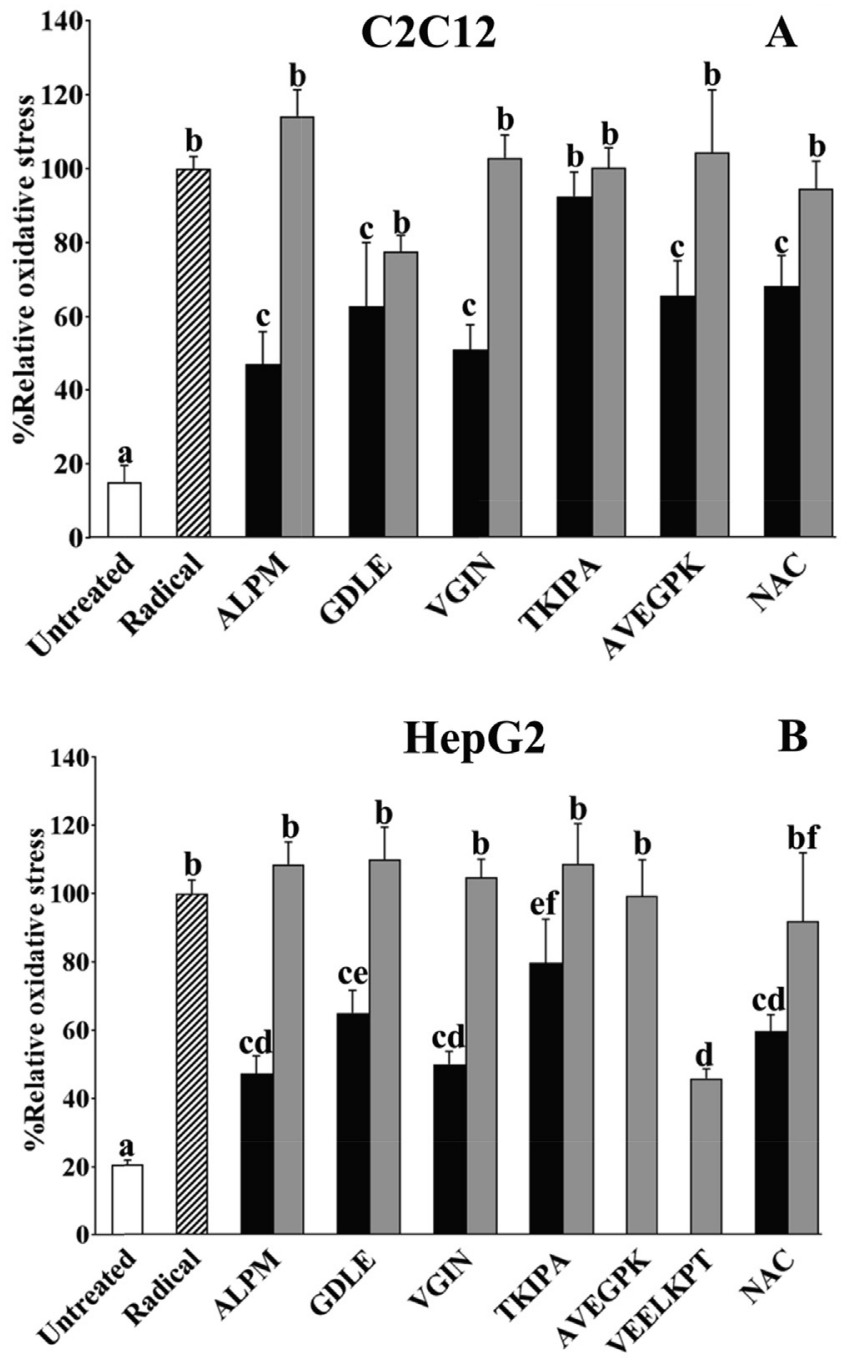

Fig. 3. Relative oxidative stress in (A) muscle (C2C12) and (B) liver (HepG2) cells after $1 \mathrm{~h}$ exposure to 5 (black bars) or $2.5 \mathrm{mM}$ (grey bars) synthesised peptides derived from whey: ALMP ( $\beta-L G)$, GDLE ( $\beta-L G)$, TKIPA ( $\beta-L G)$, VEELKPT ( $\beta$-LG) VGIN ( $\alpha$-LAC) and AVEGPK (BSA) or N-acetylcysteine (NAC) (positive control). C2C12 and HepG2 cells were seeded at a density of $8 \times 10^{4}$ cells/well for $24 \mathrm{~h}$ or $48 \mathrm{~h}$, respectively, before peptide exposure. VEELKPT was cytotoxic to C2C12 cells at 2.5 and $5 \mathrm{mM}$. VEELKPT and AVEGPK at $5 \mathrm{mM}$ were cytotoxic to HepG2. Results are expressed as \% relative to cells treated only with the peroxyl radical producer ABTS, labelled "radical". "Untreated" corresponds to cells incubated only with Hank's Balanced Salt Solution. ${ }^{*} \mathrm{p}<0.05$ indicates significant difference to radical control.

liver cells, peptides VEELKPT $(5 \mathrm{mM})$ and AVEGPK $(5 \mathrm{mM})$ were omitted as they significantly reduced cell viability by $94.1 \%$ and $92 \%$, respectively. The levels of oxidation significantly decreased between 35 and $52.6 \%$ in stressed ABAP-treated HepG2 cells with the treatment of ALPM, GDLE or VGIN ( $5 \mathrm{mM}$ ). Peptide VEELKPT ( $2.5 \mathrm{mM})$ was the most potent in decreasing cellular oxidation (51.1\%) although it also reduced cell viability by a notable $30 \%$.

\subsection{Effect of milk peptides on the release of pro-inflammatory cytokines}

THP-1 monocytes were initially differentiated into macrophages and then activated with LPS for $24 \mathrm{~h}$ prior to peptide exposure. Secreted levels of the pro-inflammatory cytokines, TNF- $\alpha$ and IL-1 $\beta$, from THP-1 macrophages exposed to peptides $(1 \mu \mathrm{M}-5 \mathrm{mM})$ are depicted in Fig. 4. Peptides ALPM, GDLE, VEELKPT, VGIN and AVEGPK ( $5 \mathrm{mM})$ significantly increased the levels of IL-1 $\beta(131.9-245.5 \%)$ in activated macrophages compared to the LPS control ( $p<0.05)$. Secretion of TNF- $\alpha$ was not altered after peptide treatment at any of the concentrations tested ( $\mathrm{p}>0.05)$. Peptides were not cytotoxic to macrophages after $24 \mathrm{~h}$ incubation (data not represented).

\section{Discussion}

Our study identified whey peptides, post SGID, that crossed Caco-2/ HT2 9 barriers. Of 6 bioavailable peptides selected, 4 inhibited free radicals in muscles and liver cells, 2 reduced cellular viability of liver cells and 5 increased secretion of IL-1 $\beta$ from stimulated macrophages. In addition, SGID of $\beta$-LG resulted in the highest concentration of free AA $(176 \mathrm{nM})$ arriving on the basolateral face of the intestinal barrier with notable levels of BCAA and sulphur-containing AA.

Picariello et al. (2013) identified peptides primarily derived from two regions within $\beta$-LG, (40-60AA and 125-135AA) and $3 \alpha$-LA peptides, within regions 56-69AA and 114-121AA, in the basolateral compartment of Caco-2 cells treated with SGID WPI. In agreement we also identified $\beta$-LG peptides from these regions (VEELKPTPE, GDLE and EVDDE) in the basolateral solution after co-culture treatment with SGID WPI and $\beta$-LG. $\alpha$-LA f(99-102) VGIN peptide was also transported across our co-culture after exposure to WPI and MPSPO. The absence of $\alpha$-LA and LF peptides in the basolateral solutions agrees with the limited number of LF peptides identified in human jejunum by Boutrou et al. (2013) and the noteworthy rapid digestion of $\alpha$-LA into free AA (Pantako \& Amiot, 2001). The large number of casein-derived compared to whey-derived peptides in MPSPO agrees with reports that there are fewer peptides released from whey proteins than from casein after gut transit (Boutrou et al., 2013). Surprisingly, several caseinderived peptides were also identified in both the apical and basolateral compartments of Caco-2/HT-29 barriers exposed to WPI, which suggest casein peptide leakage from the casein micelle during thermal processing. Five peptides from $\beta-C N$ region 133-142AA were found in the apical solution of co-cultures treated with MPSPO of which only $\beta$-CN $f$ (134-139) HLPLPL was transported across the barrier. In agreement, Wang, Wang, and Li (2016) observed HLPLPL in the basolateral side of Caco-2 monolayers treated with SGID casein hydrolysates $(10 \mathrm{mg} / \mathrm{mL})$ for $2 \mathrm{~h}$. Similar to our results, peptides from $\beta$-CN 81-92AA were also abundant in the basolateral compartment (Wang et al., 2016). Agreement of bioavailable peptides in our study with others (Picariello et al., 2013; Wang et al., 2016), together with absorptive and secretive enteric phenotype data (Ferraretto et al., 2018) supports our view that the coculture model compares well with the established 21 day differentiated Caco-2 model.

Previously, $\beta$-LG peptides $\mathrm{f}(15-18)$ VAGT, $\mathrm{f}(24-26)$ MAA and $\mathrm{f}$ (71-74) IIAE inhibited peroxyl radicals, using the oxygen reactive absorbance capacity (ORAC) assay with values between 0.33 and $1.79 \mu \mathrm{mol}$ trolox equivalents (TE)/mmol peptide (O'Keeffe, Conesa, \& FitzGerald, 2017). Of these, our study revealed that the peptides VAGT and IIAE were able to pass through the intestinal co-culture.

Previously, $\beta$-LG peptides f(19-29) WYSLAMAASDI, f(145-149) MHIRL, f(42-46) YVEEL and many of their derivatives exhibited antioxidant activity by ORAC $(0.306-2.621 \mu \mathrm{mol} \mathrm{TE} / \mu \mathrm{mol}$ peptide) (Hernández-Ledesma et al., 2005). Additionally, other studies have provided evidence that YVEEL or its derivatives survive gut transit in vivo and in vitro. Our study and that of Picariello et al. (2013) confirmed transport of the related peptide VEELKPT across the intestinal barrier. However, VEELKPT ( $5 \mathrm{mM}$ ) is cytotoxic to HepG2 and C21C12 cells undermining its ability to reduce oxidative stress at $2.5 \mathrm{mM}$ in HepG2 cells. $\beta$-LG peptide $\mathrm{f}(76-81)$ TKIPAV was identified in the most antioxidant fraction of infant formula post SGID (Hernandez-Ledesma, Quirós, Amigo, \& Recio, 2007). Derivatives of TKIPA, peptides TKIPAVFK and KIPAVFKIDAL, were also found in antioxidant fractions of buttermilk, whey proteins and skim milk powder (Bertucci, Liggieri, Colombo, Vairo Cavalli, \& Bruno, 2015; Conway, Gauthier, \& Pouliot, 2012). We confirmed transport across the intestinal barrier of TKIPA 

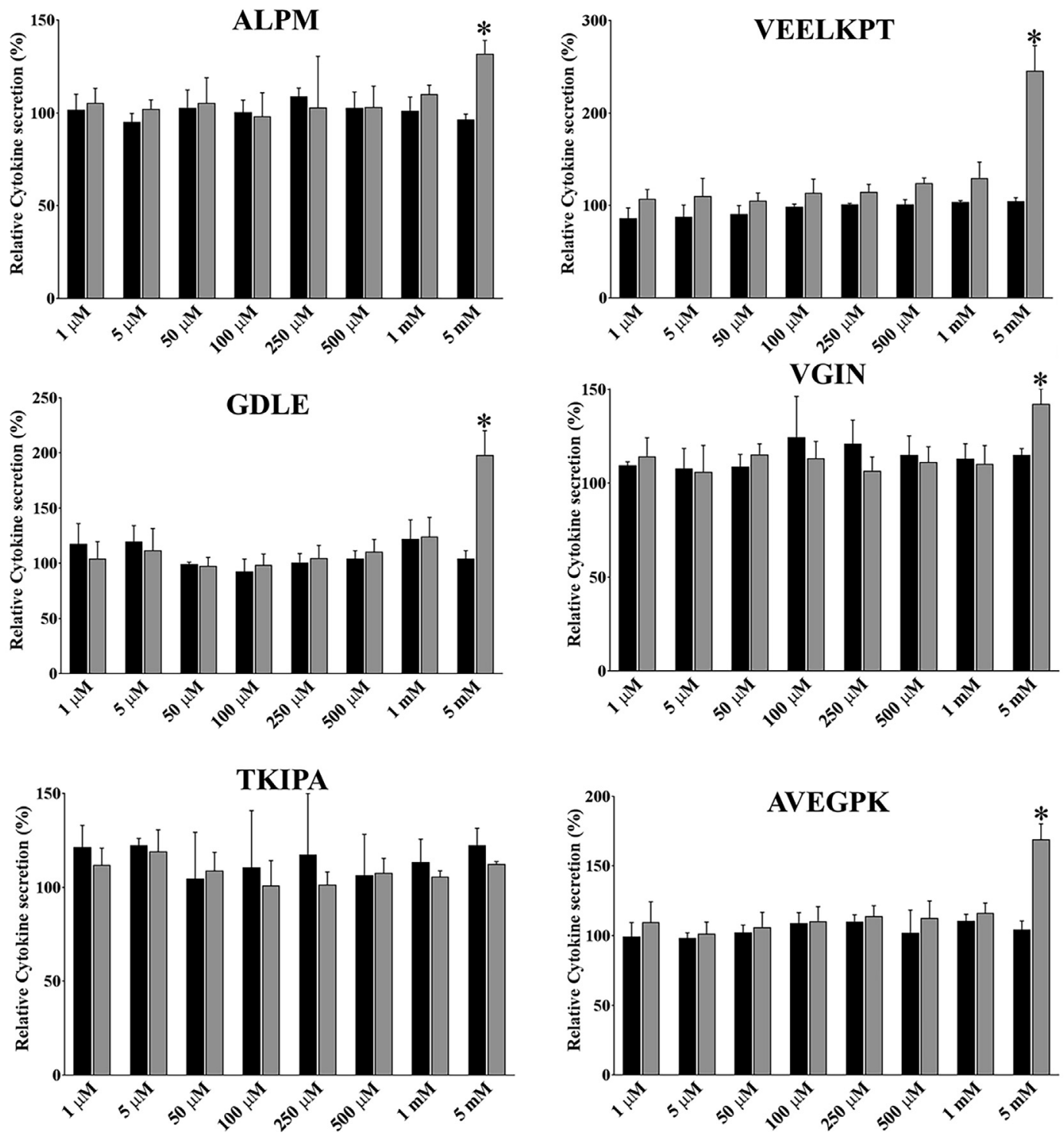

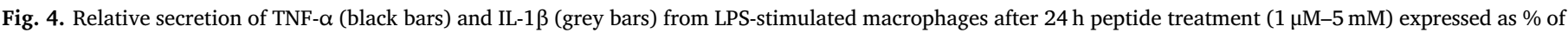

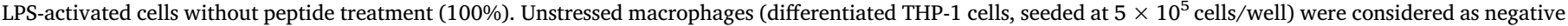
control with values of $2.6 \pm 0.2 \%$ for TNF- $\alpha$ and $3.2 \pm 0.5 \%$ for IL-1 $\beta$. ${ }^{*} \mathrm{p}<0.05$ indicates significant difference to LPS-stimulated macrophages.

but it did not protect liver and muscle cells against radicals $(2.5-5 \mathrm{mM})$.

Peptide PEGDLEI ( $\beta$-LG 50-56) was detected in whey hydrolysed by Corolase PP (Mann et al., 2015) which was capable of scavenging the synthetic radical 2,2'-Azinobis(3-ethylbenzothiazoline-6-sulfonic acid). In our study, related peptide GDLE $(5 \mathrm{mM})$ survived gut transit, was bioavailable, boosted antioxidant cellular response and protected stressed hepatocytes against cellular oxidation. The peptides $\mathrm{f}$ (101-104) INYW and $\mathrm{f}(115-118) \mathrm{LDQW}$ at $2.5 \mu \mathrm{M}$ derived from $\alpha$-LA inhibited ABTS by 100\% (Sadat et al., 2011). Although LDQW was not detected in the basolateral chamber of our Caco-2/HT-29 co-culture, VGIN was and exerted an antioxidant protection on both C2C12 and HepG2 cells.

Peptides ALPM and AVEGPK from $\beta$-LG have not been previously reported as antioxidants, however, they possess hydrophobic AA at the $\mathrm{N}$ or $\mathrm{C}$ terminus, a common characteristic of antioxidant peptides (Nielsen, Beverly, Qu, \& Dallas, 2017). Both peptides (5 mM) counteracted free radicals in C2C12. ALPM also exerted an antioxidant effect in HepG2 cells. In total, 3 dipeptides were identified in the basolateral compartments post Caco-2/HT-29 exposure to $\beta$-LG, BSA and MPSPO of which EL $(5 \mathrm{mM})$ had proven antioxidant activity by inhibiting the synthetic radical 1,1-diphenyl-2-picrylhydrazyl (Suetsuna, Ukeda, \&

\section{Ochi, 2000).}

Peptides ALPM, GDLE, VEELKPT, VGIN and AVEGPK ( $5 \mathrm{mM})$ increased the pro-inflammatory cytokine IL- $1 \beta$, but levels of TNF- $\alpha$ remained unchanged. TNF- $\alpha$ also remained unchanged in vascular endothelial cells after direct treatment with $0.5-5.0 \mathrm{mg} / \mathrm{mL}$ WPI or hydrolysates ( $\mathrm{p}>0.05$ ) (Da Silva, Bigo, Barbier, \& Rudkowska, 2017). However, TNF- $\alpha$ was significantly increased, 10-200 fold, in THP-1 cells after exposure to intact or hydrolysed WPI $(2 \mathrm{mg} / \mathrm{mL}$ ) (Kiewiet et al., 2017). Human intervention studies also provide conflicting results about the role of dairy products in the immune system (Bordoni et al., 2017). Meyer, Elmadfa, Herbacek, and Micksche (2007) reported increased levels of IL-1 $\beta$ (40\%) and TNF- $\alpha$ (63\%) on 33 healthy young women receiving 100-200 g yogurt/day compared to baseline. In contrast, $3 \mathrm{~h}$ after ingestion of $400 \mathrm{~mL}$ reduced fat milk significantly decreased plasma IL-1 $\beta$ (31\%) and TNF- $\alpha$ (27\%) in 12 overweight subjects (Nestel et al., 2012).

It is interesting to note that several peptides identified in the apical and basolateral had proven bioactivities other than antioxidant and immunomodulation. Peptides GDLE, ALPM and VGIN were encrypted within the peptides PEGDL, LPMH, KVGIN. These latter peptides were identified in WPI hydrolysates produced by pepsin and were active 
against Listeria ivanovii at $37.5 \mathrm{mg} / \mathrm{mL}$ (Theolier, Hammami, Labelle, Fliss, \& Jean, 2013). The peptides TKIPA and ALPM share 3 AA with LPMH and IPA that have proven antihypertensive activity by inhibiting the angiotensin-I-converting enzyme (ACE) in vitro. Additionally, in hypertensive rats, IPA $(8 \mathrm{mg} / \mathrm{kg})$ reduced the systolic blood pressure by $31 \mathrm{~mm} \mathrm{Hg}$ after $6 \mathrm{~h}$ administration (Mullally, Meisel, \& FitzGerald, 1997; Abubakar, Saito, Kitazawa, Kawai, \& Itoh, 1998). The BSA peptide $\mathrm{f}(568-573)$ AVEGPK was found in a bioactive fraction of Phaseolus vulgaris post SGID which was capable of $50 \%$ ACE inhibition when assayed at $105.6 \mathrm{mg}$ peptide/mL (Tagliazucchi, Martini, Bellesia, \& Conte, 2015).

Arg, Ala and Leu were predominant in the basolateral side, at concentrations of $11.1 \mathrm{nM}$ (Leu in SGID MPSPO) to $23.8 \mathrm{nM}$ (Ala in $\beta$ LG). Goulart et al. (2014) also reported that Arg and Leu were predominant basolateral AA (21.8\% and $4.1 \%$ respectively) post Caco-2 treatment with SGID fresh whey $(6 \mu \mathrm{g} / \mu \mathrm{L})$. The absence of Pro diffusion was notable in this study and agrees with previous data that Pro-containing peptides are resistant to gut enzymatic hydrolysis and epithelial proteases suggesting that peptides surviving the gut are likely to contain Pro (Boutrou et al., 2013). It also agrees with our data, where Pro appeared in $73 \%$ of the peptides identified in the basolateral compartment.

$\beta$-LG $\left(250 \mu \mathrm{g}\right.$ protein $\left./ \mathrm{cm}^{2}\right)$ delivers the most EAA $(84.7 \mathrm{nM})$, BCAA $(39.9 \mathrm{nM})$ and sulphur-containing AA $(15.9 \mathrm{nM})$ to the baslateral. Interestingly, Caco-2/HT-29 exposure to SGID $\alpha$-LA ( $250 \mu$ g protein/ $\mathrm{cm}^{2}$ ) resulted in the highest concentration of the antioxidant AA, Trp $(6.5 \mathrm{nM})$. In a human intervention study, a diet supplemented with $141 \mathrm{~g}$ of $\alpha$-LA increased the ratio between Trp and large neutral AA by $43 \%$ compared to the control diet containing casein (Markus, Olivier, \& de Haan, 2002).

Co-culture treatment with SGID proteins did not alter TEER values, whereas the paracellular permeability of lucifer yellow significantly decreased in the presence of milk peptides compared to untreated cells. This intestinal modulation may arise from the presence of transforming growth factor- $\beta$ in whey proteins, which is thought to increase the tight junction protein claudin-4 (Hering et al., 2011). The rate and mode of transport (passive $\mathrm{V}$ active) of the bioavailable peptides across the intestinal co-culture were not investigated in our study.

\section{Conclusion}

This study provides evidence that individual whey peptides survive gut transit, are bioavailable across the intestinal barrier and are bioactive on muscle and liver cell lines.

\section{Funding sources}

This research was supported by Irish Department of Agriculture, Food and the Marine (FIRM13F354). AC received a Teagasc Walsh Fellowship.

\section{Acknowledgment}

The authors thank A. McAuliffe (Teagasc) for free AA determination.

\section{Conflict of interest}

The authors declare no conflict of interest.

\section{Appendix A. Supplementary data}

Supplementary data to this article can be found online at https:// doi.org/10.1016/j.foodchem.2019.03.009.

\section{References}

Abubakar, A., Saito, T., Kitazawa, H., Kawai, Y, \& Itoh, T. (1998). Structural analysis of new antihypertensive peptides derived from cheese whey protein by proteinase $\mathrm{K}$ digestion. Journal of Dairy Science, 81(12), 3131-3138. https://doi.org/10.3168/jds. S0022-0302(98)75878-3.

Agin, D., Gallagher, D., Wang, J., Heymsfield, S. B., Pierson, R. N., Jr, \& Kotler, D. P. (2001). Effects of whey protein and resistance exercise on body cell mass, muscle strength, and quality of life in women with HIV. Aids, 15(18), 2431-2440.

Ashoush, I. S., El-Batawy, O. I., \& El-Shourbagy, G. A. (2013). Antioxidant activity and hepatoprotective effect of pomegranate peel and whey powders in rats. Annals of Agricultural Sciences, 58(1), 27-32. https://doi.org/10.1016/j.aoas.2013.01.005.

Bertucci, J. I., Liggieri, C. S., Colombo, M. L., Cavalli, S. E. V., \& Bruno, M. A. (2015) Application of peptidases from Maclura pomifera fruit for the production of active biopeptides from whey protein. LWT-Food. Science and Technology, 64(1), 157-163. https://doi.org/10.1016/j.lwt.2015.05.041.

Bordoni, A., Danesi, F., Dardevet, D., Dupont, D., Fernandez, A. S., Gille, D., Nunes Dos Santos, C., Pinto, P., Re, R., Remond, D., Shahar, D. R., \& Vergeres, G. (2017). Dairy products and inflammation: a review of the clinical evidence. Critical Reviews in Food Science and Nutrition, 57(12), 2497-2525. https://doi.org/10.1080/10408398.2014. 967385.

Boutrou, R., Gaudichon, C., Dupont, D., Jardin, J., Airinei, G., Marsset-Baglieri, A., ... Leonil, J. (2013). Sequential release of milk protein-derived bioactive peptides in the jejunum in healthy humans-. The American Journal of Clinical Nutrition, 97(6), 1314-1323. https://doi.org/10.3945/ajcn.112.055202.

Conway, V., Gauthier, S. F., \& Pouliot, Y. (2012). Antioxidant activities of buttermilk proteins, whey proteins, and their enzymatic hydrolysates. Journal of Agricultural and Food Chemistry, 61(2), 364-372. https://doi.org/10.1021/jf304309g.

Corrochano, A. R., Arranz, E., De Noni, I., Stuknytè, M., Ferraretto, A., Kelly, P. M., ... Giblin, L. (2018). Intestinal health benefits of bovine whey proteins after simulated gastrointestinal digestion. Journal of Functional Foods, 49(October), 526-535. https:// doi.org/10.1016/j.jff.2018.08.043.

Da Silva, M. S., Bigo, C., Barbier, O., \& Rudkowska, I. (2017). Whey protein hydrolysate and branched-chain amino acids downregulate inflammation-related genes in vascular endothelial cells. Nutrition Research, 38, 43-51. https://doi.org/10.1016/j. nutres.2017.01.005.

Eng, J. K., McCormack, A. L., \& Yates, J. R., III (1994). An approach to correlate tandem mass spectral data of peptides with amino acid sequences in a protein database. Journal of the American Society for Mass Spectrometry, 5(11), 976-989. https://doi. org/10.1016/1044-0305(94)80016-2.

Ferraretto, A., Bottani, M., De Luca, P., Cornaghi, L., Arnaboldi, F., Maggioni, M., .. Donetti, E. (2018). Morpho-functional properties of a differentiated Caco2/HT-29 coculture as an in vitro model of human intestinal epithelium. Bioscience Reports, 38. https://doi.org/10.1042/BSR20171497 BSR20171497.

Fox, P. F., Uniacke-Lowe, T., McSweeney, P. L. H., \& O'Mahony, J. A. (2015). Milk proteins. In P. F. Fox, T. Uniacke-Lowe, P. L. H. McSweeney, \& J. A. O'Mahony (Eds.). Dairy Chemistry and Biochemistry (pp. 145-240). New York: Springer International Publishing.

Goulart, A. J., Bassan, J. C., Barbosa, O. A., Marques, D. P., Silveira, C. B., Santos, A. F., .. Monti, R. (2014). Transport of amino acids from milk whey by Caco-2 cell monolayer after hydrolytic action of gastrointestinal enzymes. Food Research International, 63, 62-70. https://doi.org/10.1016/j.foodres.2014.01.037.

Hering, N. A., Andres, S., Fromm, A., van Tol, E. A., Amasheh, M., Mankertz, J., ... Schulzke, J. D. (2011). Transforming growth factor- $\beta$, a whey protein component, strengthens the intestinal barrier by upregulating claudin- 4 in HT-29/B6 cells. The Journal of Nutrition, 141(5), 783-789. https://doi.org/10.3945/jn.110.137588.

Hernández-Ledesma, B., Dávalos, A., Bartolomé, B., \& Amigo, L. (2005). Preparation of antioxidant enzymatic hydrolysates from $\alpha$-lactalbumin and $\beta$-lactoglobulin. Identification of active peptides by HPLC-MS/MS. Journal of Agricultural and Food Chemistry, 53(3), 588-593. https://doi.org/10.1021/jf048626m.

Hernandez-Ledesma, B., Quiros, A., Amigo, L., \& Recio, I. (2007). Identification of bioactive peptides after digestion of human milk and infant formula with pepsin and pancreatin. International Dairy Journal, 17(1), 42-49. https://doi.org/10.1016/j. idairyj.2005.12.012.

IDF (2016). The World Dairy Situation 2016. Bulletin of the International Dairy Federation 485.

Kiewiet, M. G., Dekkers, R., Gros, M., van Neerven, R. J., Groeneveld, A., de Vos, P., \& Faas, M. M. (2017). Toll-like receptor mediated activation is possibly involved in immunoregulating properties of cow's milk hydrolysates. PloS one, 12(6), e0178191. https://doi.org/10.1371/journal.pone.0178191.

Kim, J., Paik, H. D., Yoon, Y. C., \& Park, E. (2013). Whey protein inhibits iron overloadinduced oxidative stress in rats. Journal of Nutritional Science and Vitaminology, 59(3), 198-205.

Komatsu, Y., Wada, Y., Izumi, H., Shimizu, T., Takeda, Y., Hira, T., \& Hara, H. (2019). Casein materials show different digestion patterns using an in vitro gastrointestinal model and different release of glucagon-like peptide- 1 by enteroendocrine GLUTag cells. Food Chemistry, 277, 423-431. https://doi.org/10.1016/j.foodchem.2018.10. 123.

Kume, H., Okazaki, K., \& Sasaki, H. (2006). Hepatoprotective effects of whey protein on D-galactosamine-induced hepatitis and liver fibrosis in rats. Bioscience, Biotechnology, and Biochemistry, 70(5), 1281-1285. https://doi.org/10.1271/bbb.70.1281.

Lacroix, I. M., Chen, X. M., Kitts, D. D., \& Li-Chan, E. C. (2017). Investigation into the bioavailability of milk protein-derived peptides with dipeptidyl-peptidase IV inhibitory activity using Caco-2 cell monolayers. Food \& Function, 8(2), 701-709. https://doi.org/10.1039/c6fo01411a. 
Lafarga, T., Aluko, R. E., Rai, D. K., O'Connor, P., \& Hayes, M. (2016). Identification of bioactive peptides from a papain hydrolysate of bovine serum albumin and assessment of an antihypertensive effect in spontaneously hypertensive rats. Food Research International, 81, 91-99. https://doi.org/10.1016/j.foodres.2016.01.007.

Le Nevé, B., \& Daniel, H. (2011). Selected tetrapeptides lead to a GLP-1 release from the human enteroendocrine cell line NCI-H716. Regulatory Peptides, 167(1), 14-20. https://doi.org/10.1016/j.regpep.2010.10.010.

Mann, B., Kumari, A., Kumar, R., Sharma, R., Prajapati, K., Mahboob, S., \& Athira, S. (2015). Antioxidant activity of whey protein hydrolysates in milk beverage system. Journal of Food Science and Technology, 52(6), 3235-3241. https://doi.org/10.1007/ s13197-014-1361-3.

Markus, C. R., Olivier, B., \& de Haan, E. H. (2002). Whey protein rich in $\alpha$-lactalbumin increases the ratio of plasma tryptophan to the sum of the other large neutral amino acids and improves cognitive performance in stress-vulnerable subjects. The American Journal of Clinical Nutrition, 75(6), 1051-1056. https://doi.org/10.1093/ajcn/75.6. 1051.

McDermott, A., Visentin, G., De Marchi, M., Berry, D. P., Fenelon, M. A., O'Connor, P. M., ... McParland, S. (2016). Prediction of individual milk proteins including free amino acids in bovine milk using mid-infrared spectroscopy and their correlations with milk processing characteristics. Journal of Dairy Science, 99(4), 3171-3182. https://doi. org/10.3168/jds.2015-9747.

Meyer, A. L., Elmadfa, I., Herbacek, I., \& Micksche, M. (2007). Probiotic, as well as conventional yogurt, can enhance the stimulated production of proinflammatory cytokines. Journal of Human Nutrition and Dietetics, 20(6), 590-598. https://doi.org/ 10.1111/j.1365-277X.2007.00807.

Middleton, N., Jelen, P., \& Bell, G. (2004). Whole blood and mononuclear cell glutathione response to dietary whey protein supplementation in sedentary and trained male human subjects. International Journal of Food Sciences and Nutrition, 55(2), 131-141.

Minekus, M., Alminger, M., Alvito, P., Ballance, S., Bohn, T., Bourlieu, C., ... Brodkorb, A. (2014). A standardised static in vitro digestion method suitable for food - An international consensus. Food \& Function, 5(6), 1113-1124. https://doi.org/10.1039/ C3F060702J.

Mullally, M. M., Meisel, H., \& FitzGerald, R. J. (1997). Identification of a novel angiotensin-I-converting enzyme inhibitory peptide corresponding to a tryptic fragment of bovine $\beta$-lactoglobulin. FEBS Letters, 402(2-3), 99-101. https://doi.org/10.1016/ S0014-5793(96)01503-7.

Nestel, P. J., Pally, S., MacIntosh, G. L., Greeve, M. A., Middleton, S., Jowett, J., \& Meikle, P. J. (2012). Circulating inflammatory and atherogenic biomarkers are not increased following single meals of dairy foods. European Journal of Clinical Nutrition, 66(1), 25. https://doi.org/10.1038/ejcn.2011.134.

Nielsen, S. D., Beverly, R. L., Qu, Y., \& Dallas, D. C. (2017). Milk bioactive peptide database: A comprehensive database of milk protein-derived bioactive peptides and novel visualization. Food Chemistry, 232, 673-682. https://doi.org/10.1016/j. foodchem.2017.04.056.

O'Keeffe, M. B., Conesa, C., \& FitzGerald, R. J. (2017). Identification of angiotensin converting enzyme inhibitory and antioxidant peptides in a whey protein concentrate hydrolysate produced at semi-pilot scale. International Journal of Food Science \& Technology, 52(8), 1751-1759. https://doi.org/10.1111/ijfs.13448.

Pantako, O. T., \& Amiot, J. (2001). The effects of $\alpha$-lactalbumin and whey protein concentrate on $\alpha$-amino acids, calcium and phosphorus levels in blood and gastrointestinal tract of rats. Reproduction Nutrition Development, 41(3), 227-238. https:// doi.org/10.1051/rnd: 2001126.

Patel, S. (2015). Emerging trends in nutraceutical applications of whey protein and its derivatives. Journal of Food Science and Technology, 52(11), 6847-6858. https://doi. org/10.1007/s13197-015-1894-0.

Picariello, G., Iacomino, G., Mamone, G., Ferranti, P., Fierro, O., Gianfrani, C., ... Addeo, F. (2013). Transport across Caco-2 monolayers of peptides arising from in vitro digestion of bovine milk proteins. Food Chemistry, 139(1-4), 203-212. https://doi.org/ 10.1016/j.foodchem.2013.01.063.

Power-Grant, O., McCormack, W. G., Ramia De Cap, M., Amigo-Benavent, M., Fitzgerald, R. J., \& Jakeman, P. (2016). Evaluation of the antioxidant capacity of a milk protein matrix in vitro and in vivo in women aged 50-70 years. International Journal of Food Sciences and Nutrition, 67(3), 325-334. https://doi.org/10.3109/09637486.2016. 1153607.

Purpura, M., Lowery, R. P., Joy, J. M., De Souza, E. O., Kalman, D., Jäger, R., \& Wilson, J. (2014). A comparison of blood amino acid concentrations following ingestion of rice and whey protein isolate: A double-blind, crossover study. Journal of Nutrition and Health Sciences, 1(3), https://doi.org/10.15744/2393-9060.1.306.

Roeseler, D. A., McGraw, N. J., Butteiger, D. N., Shah, N., Hall-Porter, J., Mukherjea, R., \& Krul, E. S. (2017). Muscle protein signaling in C2C12 cells is stimulated to similar degrees by diverse commercial food protein sources and experimental soy protein hydrolysates. Journal of Agricultural and Food Chemistry, 65(14), 2956-2964. https:// doi.org/10.1021/acs.jafc.6b05460.

Sadat, L., Cakir-Kiefer, C., N’Negue, M. A., Gaillard, J. L., Girardet, J. M., \& Miclo, L. (2011). Isolation and identification of antioxidative peptides from bovine $\alpha$-lactalbumin. International Dairy Journal, 21(4), 214-221. https://doi.org/10.1016/j. idairyj.2010.11.011.

Sanchón, J., Fernández-Tomé, S., Miralles, B., Hernández-Ledesma, B., Tomé, D., Gaudichon, C., \& Recio, I. (2018). Protein degradation and peptide release from milk proteins in human jejunum. Comparison with in vitro gastrointestinal simulation. Food Chemistry, 239, 486-494. https://doi.org/10.1016/j.foodchem.2017.06.134.

Suetsuna, K., Ukeda, H., \& Ochi, H. (2000). Isolation and characterization of free radical scavenging activities peptides derived from casein. The Journal of Nutritional Biochemistry, 11(3), 128 -131. https://doi.org/10.1016/S0955-2863(99)00083-2.

Tagliazucchi, D., Martini, S., Bellesia, A., \& Conte, A. (2015). Identification of ACE-inhibitory peptides from Phaseolus vulgaris after in vitro gastrointestinal digestion. International Journal of Food Sciences and Nutrition, 66(7), 774-782. https://doi.org/ 10.3109/09637486.2015.1088940.

Tipton, K. D., Elliott, T. A., Cree, M. G., Wolf, S. E., Sanford, A. P., \& Wolfe, R. R. (2004). Ingestion of casein and whey proteins result in muscle anabolism after resistance exercise. Medicine \& Science in Sports \& Exercise, 36(12), 2073-2081.

Théolier, J., Hammami, R., Labelle, P., Fliss, I., \& Jean, J. (2013). Isolation and identification of antimicrobial peptides derived by peptic cleavage of whey protein isolate. Journal of Functional Foods, 5(2), 706-714. https://doi.org/10.1016/j.jff.2013.01. 014.

Vermeirssen, V., Deplancke, B., Tappenden, K. A., Camp, J. V., Gaskins, H. R., \& Verstraete, W. (2002). Intestinal transport of the lactokinin Ala-Leu-Pro-Met-His-IleArg through a Caco-2 Bbe monolayer. Journal of Peptide Science: An Official Publication of the European Peptide Society, 8(3), 95-100. https://doi.org/10.1002/psc.371.

Walrand, S., Gryson, C., Salles, J., Giraudet, C., Migné, C., Bonhomme, C., ... Boirie, Y. (2016). Fast-digestive protein supplement for ten days overcomes muscle anabolic resistance in healthy elderly men. Clinical Nutrition, 35(3), 660-668. https://doi.org/ 10.1016/j.clnu.2015.04.020.

Wang, C., Wang, B., \& Li, B. (2016). Bioavailability of peptides from casein hydrolysate in vitro: Amino acid compositions of peptides affect the antioxidant efficacy and resistance to intestinal peptidases. Food Research International, 81, 188-196. https:// doi.org/10.1016/j.foodres.2015.12.013. 